\title{
RELATIONSHIP MANAGEMENT IN DOWNSTREAM SUPPLY CHAIN: A PREDICTOR OF PERFORMANCE AMONG SELECTED PHARMACEUTICAL COMPANIES IN KAMPALA, UGANDA
}

\author{
Samuel Pule ${ }^{1^{*}} \&$ Charles Kalinzi ${ }^{2}$ \\ ${ }^{1}$ Department of Procurement \& Marketing, Kampala International University \\ ${ }^{2}$ Department of Procurement, Marketing \& Supply Chain, Kyambogo University
}

\begin{abstract}
In this article, we examine the extent at which relationship management in downstream supply chain predicts performance. Specifically, the paper assesses the extent at which collaborative and transactional customer management predicts performance of selected pharmaceutical companies in Kampala. The researchers employed case studies and cross-sectional research designs, which used a researcher's made questionnaire, for data collection. Data was analyzed using means and regressions, which were computed using the statistical package for social scientist (SPSS). Findings revealed a high extent of relationship management in downstream supply chain at an average mean of 4.23, as well as, high levels of pharmaceutical performance at an average mean of 4.29. When these results were regressed, it was indicated that, relationship management in supply chain highly predicts pharmaceutical performance in Kampala $\left(R^{2}\right.$ value $74 \%$ and Sig. 0.014). The researchers therefore recommends managers, policy makers and practitioners to give considerable attention in managing relationships within the downstream supply chain, and in particular, ensure appropriate collaborations with customers. In this way, organizations will retain their customers, increase sales levels and market shares, which will consequently improve organizational performance.
\end{abstract}

\section{KEY WORDS}

Relationship Management, Downstream Supply Chain, Collaborative Relationships, Transactional Relationships, Performance

\section{INTRODUCTION}

The current economic realities of a highly volatile market and negligible or even negative economic conditions, require enterprises to desist from traditional business practices that are ego centric in nature, and employ sustainable practices of collaboration that enhance business survival and growth in hard times [1]. Managing relationships in downstream supply chain has been one of the most recommended contemporary business practices that organizations can employ to achieve competitive advantage, especially in the current volatile markets and

DOI: $10.5121 / \mathrm{ijmvsc} .2014 .5305$ 
environmental conditions. Forging synergies, collaborating with customers and trading partners is one most effective way of achieving high performance within an organization. Fiala (2004) as cited by [29] argues that such strategic alliances promote efficiency, lower operational costs and enhance supply chain visibility, which is crucial in mitigating supply chain problems or risks that may impede the performance of any given organization. Similarly, [21] maintains that, downstream relationship management not only lowers operational costs, but also helps mitigate against the bullwhip effect. A problem commonly caused by lack of downstream or demand information and irrational decision making in the supply chain process [15]. Collaborating with customers as a key component of relationship management is one best way in which such a problem can be mitigated. This is because collaboration increases demand information that can support effective forecasting within the supply chain to allow control and strategizing against such demand swings [12] which are responsible for the bullwhip effect thus improved organizational performance.

The growth of many giant retail companies all over the world is mainly attributed to the way such organizations manage their clients. Procter and Gamble for instance, forged a strategic alliance with Wal-Mart to ensure that its products are brought closer to consumers markets; as a result the two companies have grown from $\$ 375$ million since their relationship began in 1988 to over \$4billion today [18]. Similarly, companies like Tesco, Costco, and Cardinal Health have grown large simply because they accord significant amount of attention to downstream collaboration. Through collaborations and other forms of strategic alliances such companies effectively improved their supply chain processes, which explains their success in terms of business growth and expansion. [33] maintains that companies that embrace collaborations within the supply chain network are more likely to enhance their operations to higher levels.

Unfortunately, in many developing countries, Uganda inclusive, companies do not give considerable attention to downstream relationship management. This has been depicted in form of low levels of technological integration that aid supply chain integrations and relationships. [32] maintains that technological integration plays a pivotal role in promoting relationship and integration within the supply chain network. Its absence therefore affects the management of relationships within the supply chain process. [24] points out that technological integration in Uganda is only at $6 \%$ among companies. This is too low to foster comprehensive country collaboration or relationships among companies. Secondly, the limited absorption level of information technology has been a major contributor to the low level of supply chain development in many developing countries or continents like Africa. For instance, in Nigeria and many other West African countries, companies easily abandoned new technological integrations simply because they feel such technologies cannot address their needs on the premise that they are not designed basing on the local needs of people, but rather adopted from other external communities, societies or agencies [26]. This makes it inappropriate in solving the needs of local companies, which has consequently made many companies reluctant to adopt such technologies, thus poor supply chain integration, customer management and general organizational performance. It is on the basis of such less integrated downstream supply chains that this study sought to examine, why many organizations in developing countries, Uganda inclusive, have not fully embraced relationships in downstream supply chain, yet they have been known for promoting bulk purchasing, customers retention and downstream visibility whose concepts are key in enhancing organizational performance. 


\subsection{Research Objectives}

To examine the extent at which relationship management in downstream supply chain predicts performance of selected pharmaceutical companies in Kampala, Uganda. Specifically, the study aimed at assessing the extent at which collaborative and transactional customer management predicts performance of selected pharmaceutical companies in Kampala, Uganda.

\subsection{Research Hypotheses}

From the above objectives, the study hypothesized that; (1) relationship management in downstream supply chain is not a predictor of performance among selected pharmaceutical companies in Kampala; (2) collaborative customer management is not a predictor of performance among selected pharmaceutical companies in Kampala; and lastly, (3) transactional customer management is not a predictor of performance among selected pharmaceutical companies in Kampala, Uganda.

\section{REVIEW OF RELATED LITERATURE}

\subsection{Relationship Management in Downstream Supply Chain and Company Performance}

Relationship management is a process in which an organization(s) creates long-term understanding with its customers or business partners for strategic value, whereas, downstream supply chain, which is sometimes referred to as 'outbound logistics', involves salespeople, customers service representatives, prospectors, account managers, and field support telemarketers who place phone calls out to customers [35]. A combination of the two concepts is what we are referring to as relationship management in downstream supply chain. [8] asserts that, this type of relationship involves establishing and maintaining long-term bonds with customers, rather than acting as if each sale transaction is a complete new encounter. Company or organizational performance on the other hand, is the extent at which an organization achieves its intended goals. When an organization meets its intended objectives sufficiently then performance is considered to be good or above expectations, but if it fails then performance is considered poor or below expectations. Therefore, proper management of downstream relationships boast organizational performance in a number of ways, including but not limited to; lowering marketing costs, encouraging bulk purchases among customers, and creating a supportive atmosphere between the seller and buyers, which boasts organizational performance in terms of increased sale and market growth. [11] asserts that downstream relationships help reduce demand uncertainty, a primary factor in causing the bullwhip effect within the supply chain process. Managers therefore ought to forge close relationships with customers in order to control against unnecessary demand fluctuations through increased forecasting and visibility in the supply chain. In addition, such collaborations will allow members of the supply chain to effectively stock levels, control costs and increase demand planning hence improving organizational competitiveness.

\subsection{Collaborative Customer Management and Company Performance}

Collaborative customer management is a system used to organize information about customers, their needs, company information, and sales information [35]. It is a broad term, which covers 
all aspects of the way companies manage their relationships with downstream customers [34]. Collaborative customer management determines organizational performance in a number of ways, including among others; enhancing buyer-seller understanding, increasing supply chain visibility, downstream efficiency, which consequently leads to improved organizational performance through increased sales, profitability and market assurance [14], [25], and [29]. Given these benefits though, it should be noted that, a collaborative management can sometimes be detrimental to an organization, because confidential information can easily leak or be exposed to a company's competitors by its trading partners. If this happens, it can affect organizational competitiveness hence leading to its collapse. Managers therefore, ought to take precautions before sharing strategic information with their supply chain partners. Though most scholars generally contend towards collaborative customers management, [2] points out that realizing it may sometimes require an organization to invest heavily in information technologies, yet such technologies are usually very expensive and require much in terms of staff sensitization, training and orientation, which most organizations, especially those in developing country, like Uganda cannot easily afford [25].

Talking of Uganda, very few companies can collaborate extensively with their clients. This is because of the limited technological capacity that the country has [24]. Those few that are technologically integrated mainly collaborate in terms of e-mail, fax technologies, and telephone calling. This somehow is not sufficient. The need for high-tech collaborative systems like, electronic data interchange and enterprise resource planning is paramount for effective supply chain management. World over, the integration of technology power has been commended for supporting economic growth. In light of this, the Ugandan pharmaceutical industry needs to borrow a leaf from successful stories of companies like Wal-Mart, Tesco, Costco, and Cardinal Health which have used technology to become global powers. Although some elements of eSourcing, and e-Collaboration were indicated in PINE Pharmacy, Fist Pharmacy and Boots Pharmaceuticals it was minimal and was only restricted to making orders, tracking customer stock levels and informing each other on new market developments. Nothing like detailed customer consultations, joint planning and visits were indicated. Nevertheless, they have some level of information interchange which is essential for the growth and development of any supply chain. With these prospects, [11] maintains that the best way in which companies can achieve competitive advantage is through forging synergies and alliances in order to increase the flow of information amongst them. In this way, efficiency will be enhanced; certainty increased in the supply chain, thus improved organizational performance.

\subsection{Transactional Customer Management and Company Performance}

Transactional customer management is a form of business dealing whereby a company or an organization does not closely relate with its customers. It is sometimes known as arms-length or adversarial customers management. This is because of the limited information exchange among trading partners, discreteness in purchasing and non-reciprocal tendencies that are characterized with little or no supportive arrangements between the seller and buyer [22]. Every company lives on its own. [6] argues that, this kind of business approach is perhaps suitable for routine purchases and not strategic intensions. Organizations that are therefore seeking competitiveness need not to delve in this kind of relationship, which is ego centric in nature but rather engage in strategic or collaborative customer management approaches, which encourage bulk purchase, joint planning and assistance for each other. Unfortunately in Uganda, majority of the small and medium enterprise (SMEs) are inclined to this kind of business practice [23] which explains the limited growth of most SMEs within the country. A little different though, the pharmaceutical 
sector indicated a relatively high level of customer collaborative management, as compared to transactional practices. Indeed, if compared with other sectors, the pharmaceutical industry has recorded high proliferation in recent years with over 400 licensed pharmaceutical companies in Uganda [28]. This is mainly attributed to the way the industry is managed and regulated by the National Drug Authority. The authority should partly be credited for this growth because of its role in streamlining the operations of pharmacies within the country. Secondly, the need for increased visibility and minimized supply chain uncertainties in the pharmaceutical industry has seen many companies collaborate and shun away from transactional business practices, which limits information flow within the supply chain echelon.

\section{RESEARCH METHODOLOGY}

\subsection{Research Design, Study Population and Sample Sizes}

The study employed case studies and cross-sectional research designs to gather and analyses data. Cross-sectional design for instance, was applied in form of collecting data from different social settings or pharmacies, which was done at the same period of time, whereas case studies were used to collect data in different units of analysis. This helped provide detailed data and descriptions even though they were located in different social settings. The study samples were determined using the [20] size determination formula. Data was mainly primary in nature and it was collected using a five point researcher's made likert scale questionnaire. The study mainly used sample random sampling method to collected data. This is because respondents were widely spread, as indicated in table A.

Table A: Showing the Population, Sample Size and Sampling Techniques of the Study

\begin{tabular}{lccc}
\hline $\begin{array}{l}\text { Categories of Respondents/ } \\
\text { Pharmaceutical Companies }\end{array}$ & Population & Sample Size & Sampling Technique \\
\hline PINE Pharmacy & 15 & 15 & Simple Random \\
PAROMBO Pharmacy & 10 & 10 & Simple Random \\
VINE Pharmacy & 35 & 28 & Simple Random \\
ICON Pharmacy & 20 & 18 & Simple Random \\
FREICCA Pharmaceuticals & 25 & 24 & Simple Random \\
KAM CARE Pharmaceuticals & 15 & 15 & Simple Random \\
MIDAS Care Uganda & 10 & 08 & Simple Random \\
ESCORTS Pharmaceuticals & 15 & 12 & Simple Random \\
OCEAN Pharmaceutical & 18 & 18 & Simple Random \\
GOOD DAY Pharmacy & 20 & 17 & Simple Random \\
GITTOES Pharmaceuticals & 30 & 24 & Simple Random \\
FIRST Pharmacy & 15 & 15 & Simple Random \\
ABACUS Pharmaceuticals & 25 & 13 & Simple Random \\
PLANET Pharmacy & 25 & 24 & Simple Random \\
SUPREME Pharmacy & 10 & 10 & Simple Random \\
Boots Pharmaceuticals & 15 & 14 & Simple Random \\
\hline Total & $\mathbf{3 0 3}$ & $\mathbf{2 6 5}$ & \\
\hline
\end{tabular}

Source: Primary Data Sampled using the Krejcie and Morgan Sampling Technique, (1970) 


\subsection{Data Quality and Analysis}

Before data collection, consultations were made from fellow lecturer and pharmacists to validate the research instrument. After this, data was collected, coded and entered into the SPSS. Validity test were performed between downstream supply chain relationship management and company performance. The content validity index for relationship management in downstream supply chain was 0.88 , while that of pharmaceutical performance was at 0.84 . When the two indices were combined, it came to 0.86 , which was acceptable. When the content validity index of an instrument is above 0.70 then it qualifies to be accepted as valid, [4]. Similarly, reliability tests were computed and the Cronbach's alpha coefficient was 0.82, which was also acceptable. Further, Amin points out that, when an alpha is equal to 0.5 or higher reliability is regarded to be sufficient. To validate the instruments further, a factor analysis was performed on the two main variables of study as follows; relationship management in downstream supply chain indicated an average factor loading of 0.92 , while that of pharmaceutical performance was at 0.87 , which was acceptable. In light of these tests, the extent of relationship management in downstream supply chain and the level of pharmaceutical performance were measured using means. Regressions techniques on the other hand, were used to measure the degree at which, relationship management predicted pharmaceutical performance. Numerical values and response modes were used to interpret the means as indicated in table B:

Table B: Numerical values and response modes used to interpret the Means

\begin{tabular}{lll}
\hline Mean Range & Response Mode & Interpretation \\
\hline $4.30-5.00$ & Strongly Agree & Very High \\
$3.50-4.20$ & Agree & High \\
$2.70-3.40$ & Not Sure & Undecided \\
$1.90-2.60$ & Disagree & Low \\
$1.10-1.80$ & Strongly Disagree & Very Low \\
\hline
\end{tabular}

Source: Mabonga (2012).

\section{FINDINGS}

\subsection{Relationship Management in Downstream Supply Chain}

The extent of relationship management in downstream supply chain among pharmaceutical companies in Kampala was high at average of 4.23. This was as due to very high results on collaborative customer management as compared to the moderate extent of transitional customer management as indicated in the subsequent sections.

\subsubsection{Collaborative Customer Management}

Results indicated a very high level of collaborative customer management among pharmaceutical firms in Kampala, with an average mean of 4.37. This was attributed to very high responses on the issues of; collaborative customer relationships helping the company retain customers thus increasing sale levels and profitability (mean $=4.73$ ), collaborative customer 
relationships helping the company increase their sales levels (mean $=4.64)$, the company usually practices collaborative relationships with its customers $($ mean $=4.60)$, collaborative customer relationships helps the company increase market shares (mean $=4.58)$, extending credit facilities to customers with whom the company collaborative with $($ mean $=4.53)$, the company listens to the complaints of its collaborative customers than the non-collaborative ones (mean $=4.46$ ), the company extends priority of service to collaborative customers as compared to those it does not collaborate with (mean $=4.32$ ), the company offers discount facilities to collaborative customers even though they had not purchased in bulk (mean $=4.18$ ), collaborative customers usually do not make prompt payments when purchasing products from the company (mean $=3.84$ ), and lastly, delivery of services or products is rarely based on cash for the company's collaborative customers $($ mean $=3.81)$.

\subsubsection{Transactional Customers Management}

A moderate extent of transactional customer management was revealed among pharmaceutical companies in Kampala, with an average mean of 4.09. This was due to moderate responses on the issues of; transactional customers making prompt payment whenever they were purchasing a given product from a company (mean $=4.58$ ), delivery of services or products is based on cash to the company's transactional customers (mean $=4.47$ ), the company practice transactional relationship with some of its clients (mean $=4.40$ ), the company offers discount facilities to customers who purchase in bulk even if they are transactional purchasers (mean $=4.33$ ), transactional customer management helps the company increase its sales levels (mean $=4.21$ ), transactional customer management helps the company increase its market shares (mean $=4.04)$, transactional customer management helps the company retain customers which in turn increasing sale levels and profitability (mean $=3.94$ ), the company extends priority of service to transactional customers than those it collaborate with (mean $=3.81$ ), the company listens to the complaints of its transactional customers as compared to those it collaborate with (mean $=3.62$ ), and lastly, the company extends credit facilities to customers it does not collaborative with $($ mean $=3.48)$.

\subsection{Pharmaceutical Performance}

The level of pharmaceutical performance in Kampala was also high at an average mean of 4.29. This was because of very high responses on the level of market shares, as compared to the level of sales management as follows:

\subsubsection{Sale Management}

Findings postulated a high level of sale management among pharmaceutical companies in Kampala, with an average mean of 4.24. This was attributed to high responses on the issues of; collaborative customers strategies always attracting more sale (mean $=4.65)$, company's sales levels increasing ever since it started the business (mean $=$ mean $=4.62)$, company's business profits increasing over years as a result of increase in sales (mean $=4.59)$, the company always meeting its sale targets (mean $=4.43$ ), the company having enough capital invested to generate desired profits (mean $=4.41$ ), the company's profitability margins commensurate with the sales levels of the business (mean $=4.41$ ), the company gives discount which attracts more sales (mean $=4.38$ ), the company sales are sufficient as to capital employed (mean $=4.35$ ), the company's credit terms are in position to attract more customers (mean $=4.22)$, the company 
rarely receives bad debtors (mean $=3.91$ ), and lastly, the company's non-collaborative customer strategies have always attracted more sales $($ mean $=2.62)$

\subsubsection{Market Share}

A very high level of market share was showed among pharmaceutical companies in Kampala, with an average mean of 4.34. This was as a result of very high responses on the issues of; the number of our clients has been increasing over years (mean $=4.72)$, the products the company deals in are always appreciated by its clients (mean $=4.69)$, collaborative customer strategies have always attracted more customers (mean $=4.63$ ), transactional customer strategies have always attracted many customers (mean $=4.58$ ), the customers the company serve always come back to buy from it (mean $=4.58$ ), the company has captured a substantial number of clients from other regions (mean $=4.53$ ), the company has an assured market for the products it deals in $($ mean $=4.50)$, the company has business outlets in other regions (mean $=4.41)$, the company has loyal customers whom it can depend on (4.37), there are many other businesses similar to ours in the same area (mean $=4.30)$, the company believes it shall become market leaders with time (mean $=4.23$ ), the company believes its among the market leaders in the industry (mean = 3.90 ), the company has more customers than its competitors (mean $=3.82$ ), and lastly, the company has a substantial number of clients in Kampala than our competitors ( mean $=3.52$ )

\subsection{Measuring the Predictability amongst Study Variables}

This section presents predictability of relationship management in the downstream supply chain on the performance of pharmaceutical companies in Kampala. It also provides the relative predictability of constructs like customer collaboration management and transactional customer management on organizational performance as shown in table B.

Table B: Shows the Regression Model Summary of Relationship Management in Downstream Supply Chain \& Performance of Selected Pharmaceutical Companies in Kampala

\begin{tabular}{|l|c|c|c|c|c|c|c|}
\hline \multicolumn{7}{|c|}{ Model Summary } \\
\hline Regressed Variables & R & R Square & $\begin{array}{c}\text { Adjusted } \\
\text { R Square }\end{array}$ & F & Sig & Interpretation & Decision on H \\
\hline $\begin{array}{l}\text { RMDSC \& Phamaceutical } \\
\text { Performance }\end{array}$ & $.863^{\mathrm{a}}$ & .742 & .721 & 28.411 & .014 & $\begin{array}{c}\text { Significantly } \\
\text { Predicts }\end{array}$ & Rejected \\
\hline
\end{tabular}

Source: Primary Data

Relationship Management in Downstream SC (RMDSC)

Table B shows regression results on the first and main hypothesis of the study, which stated that, relationship management in downstream supply chain, is not a predictor of performance among Pharmaceutical. Findings revealed that, relationship management in downstream supply chain positively and significantly predict performance of selected pharmaceutical companies in Kampala with $\mathrm{R}^{2}$ value $74 \%$, and Sig. value 0.014 , which resulted into the rejection of the null hypothesis. This implies that, $74 \%$ variability in pharmaceutical performance is explained by relationship management in the downstream supply chain, while the remaining $26 \%$ is the unexplained variables. The researchers therefore, conclude that, relationship management in 
downstream supply chain highly predicts performance among selected pharmaceutical companies in Kampala.

Table C: Shows the Coefficients of the Study and how they predict Pharmaceutical Performance in Kampala, Uganda

\begin{tabular}{|c|c|c|c|c|c|c|}
\hline \multicolumn{7}{|c|}{ Coefficients } \\
\hline \multirow[t]{2}{*}{ Constructs of RMDSC } & \multicolumn{2}{|c|}{$\begin{array}{l}\text { Unstandardized } \\
\text { Coefficients }\end{array}$} & \multirow{2}{*}{$\begin{array}{c}\text { Standardized } \\
\text { Coefficients } \\
\text { Beta }\end{array}$} & \multirow[t]{2}{*}{ Sig. } & \multirow[t]{2}{*}{ Interpretation } & \multirow[t]{2}{*}{$\begin{array}{c}\text { Decision on } \\
\mathrm{H}_{0}\end{array}$} \\
\hline & B & $\begin{array}{l}\text { Std. } \\
\text { Error }\end{array}$ & & & & \\
\hline (Constant) & -1.372 & .613 & & .000 & $\begin{array}{l}\text { Significantly } \\
\text { Predicts }\end{array}$ & Rejected \\
\hline $\begin{array}{l}\text { CCM \& Performance of } \\
\text { Pharmaceutical Companies }\end{array}$ & .762 & .180 & .684 & .031 & $\begin{array}{l}\text { Significantly } \\
\text { Predicts }\end{array}$ & Rejected \\
\hline $\begin{array}{l}\text { TCM \& Performance of } \\
\text { Pharmaceutical Companies }\end{array}$ & .174 & .151 & .086 & .018 & $\begin{array}{l}\text { Significantly } \\
\text { Predicts }\end{array}$ & Rejected \\
\hline
\end{tabular}

Source: Primary Data

Collaborative Customers Management (CCM)

Transactional Customers Management (TCM)

From table $\mathrm{C}$ above, results on the second and third hypothesis of the study are given. Beginning with the second hypothesis which that, collaborative customer management is not a predictor of performance among selected pharmaceutical companies in Kampala, Uganda. It was indicated that, collaborative customer management positively and significantly predicts performance among selected pharmaceutical companies in Kampala by an $r^{2}$ value $76 \%$ and Sig. 0.031, which resulted into the rejection of the null hypothesis. To digest this statistics further, one would say that, $76 \%$ change in pharmaceutical performance is due to collaborative customer management. The researchers therefore, conclude that, collaborative customer management highly predicts performance among pharmaceutical companies in Kampala.

The third hypothesis stated that, transactional customer management is not a predictor of performance among Pharmaceutical companies in Kampala, Uganda. Findings showed that, transactional customer management positively and significantly predicts performance in pharmaceutical companies in Kampala with $r^{2}$ value $17 \%$ and Sig. value 0.018 . This implies that, $17 \%$ of the variations in pharmaceutical performance can be explained by transactional customer management practices. Despite rejecting the hypothesis, the extent at which, transactional customer management predicts performance among pharmaceutical companies was observed to be generally low. The researchers therefore, conclude that, transactional customer management weakly predicts performance among pharmaceutical companies in Kampala, Uganda.

\section{DISCUSSIONS AND RECOMMENDATIONS}

\subsection{Relationship Management in Downstream Supply Chain and Company Performance}

A high extent of relationship management in SC was indicated among pharmaceutical companies in Kampala with an average mean of 4.23 . When this result was regressed against 
pharmaceutical performance, it was revealed that, relationship management in downstream supply chain highly predicts pharmaceutical performance in Kampala $\left(\mathrm{R}^{2}\right.$ value $74 \%$, and Sig. value 0.014 ). This finding is in agreement with studies like [10], [30] and [31] conducted in the line of downstream supply chain management. These provide clear justifications on the influence of downstream supply chain management on organizational performance. However, even though [27] also largely contends on the role of downstream supply chain management in Uganda, she has some reservations on the practicality of managing relationships within the country. This is in agreement with [23] who conducted a study on SMEs in Eastern Uganda, and found out that, very many organizations were still bogged in transactional management of business with limited collaborative tendencies. This is detrimental in achieving organizational competitiveness because of the high costs associated in such business practices [12], [16] and [22]. Managers are therefore encouraged to engage in collaborative practices that promote bulk purchasing, supply chain visibility and forecasting hence effective demand planning, and improved organizational performance.

\subsection{Collaborative Customer Management and Company Performance}

A high level of collaborative customer management among pharmaceutical companies in Kampala was indicated with an average mean of 4.37. This was then regressed against pharmaceutical performance, and it was revealed that, collaborative customer management highly predicts pharmaceutical performance $\left(r^{2}\right.$ value $76 \%$, and Sig. value 0.031$)$. Similarly, [19] conducted a study on a process oriented perspective on customer relationship management and found out that, collaborative customer management practices strongly predict organizational performance. This is in agreement with studies like [12], [17] and [25] who contend towards the role of collaborative customer management in enhancing organizational performance. On a negative note however, [30] observe that achieving a collaboration arrangement with your customer may require an organization to invest in information technology. This is not easy for most companies in the developing world due to costs associated with such installations. This study therefore recommends managers to always find ways of moving at par with the rest of the world. Yes, it is expensive to go technology, but this is the only way organizations can effectively collaborate with their clients and remain competitive in the global arena.

\subsection{Transactional Customer Management and Company Performance}

A moderate level of transactional customer management among pharmaceutical companies in Kampala was revealed with an average mean of 4.09. This was then regressed against performance, and findings suggested that, transactional customer management weakly predicts pharmaceutical performance in Kampala $\left(r^{2}\right.$ value of $17 \%$, and Sig. 0.018). Although the research hypothesis was rejected in this case, the level at which transactional customer management predicts pharmaceutical performance was very weak. This suggests that, even if a considerable amount of attention is devoted on transactional practices little is likely to be realized in terms of organizational performance. This is because such transactional business approaches do not appreciate long-term orientations that are known to foster mutual assistance and problem solving between buyers and sellers [17]. Transactional business practices are rather based on arm-length principles, which are known have limited information exchange between buyers and sellers of goods and thus poor supply chain relations [16], [22]. In this regard, managers are encouraged not to accord considerable attention on transaction business practices since they have little to offer in terms of organizational performance, but rather devote enough in 
terms of collaborative customer management, which have proved viable in promoting bulk purchasing, enhancing supply chain planning and visibility, and consequently, improved organizational performance.

\section{CONCLUSIONS}

From the findings, the researchers concluded on the hypotheses as follows: (1) relationship management in downstream supply chain highly predicts performance among selected pharmaceutical companies in Kampala, (2) collaborative customer management highly predicts performance among selected pharmaceutical companies and lastly, (3) transactional customer management weakly predicts performance among selected pharmaceutical companies in Kampala. In this regard, managers, decision makers and practitioners need to offer considerable attention on managing downstream relationship, in particular, ensure appropriate collaborations with their customers. This will help an organization(s) retain more of its customers, increased sales level and market shares, thus improving organizational performance.

\section{REFERENCES}

1. Accenture (2009). Customer Centricity in Downstream Energy: The Winning Edge for High Performance in Uncertain Times, Copyright (C 2009 Accenture

2. Adiele, K.C., \& Gabriel, J.M.O., (2013). "Customer Relationship Management and Bank Performance in Nigeria: An Empirical Validation Study”, International Journal of Science and Research (IJSR), India Online ISSN: 2319-7064, Vol. 2, Issue 1.

3. AlSudairi, M., Vasista, T.G., Zamil, A.M., \& Algharabat, R., (2012). "Mitigating the Bullwhip Effect with e-Word Of Mouth: e-Business Intelligence Perspective", International Journal of Managing Value and Supply Chains, DOI: 10.5121, Vol. 3, No. 4.

4. Amin, M.E., (2005). Social Science Research: Conception, Methodology \& Analysis. Makerere University Printery, Uganda

5. Awad, H.A.H., \& Nassar, M.O., (2010). "Supply Chain Integration: Definition \& Challenges", Proceedings of the international Multi conference of Engineer \& Computer Scientist, ISBN 978988-17012-8-2, Vol. 1, Hong Kong

6. Baily, P., Farmer, D., Crocker, B., Jessop, D., \& Jones, D., (2008). Procurement Principles and Management $\left(10^{\text {th }}\right.$ ed $)$. Prentice Hall, Financial Times, England

7. Barnes, J. (1954). "Class and Committees in a Norwegian Island Parish", Human Relations, Vol. 7, pp. 39-58.

8. Berman, B., \& Evans, J.R., (2004). Retail Management: A Strategic Approach: (9 ${ }^{\text {th }}$ ed). Pearson Education, Inc, Upper Saddle River, New Jersey

9. Callon, M., (1986). "The Sociology of an Actor-Network: The Case of the Electric Vehicle." In Mapping the Dynamics of Science and Technology: Sociology of Science in the Real World, edited by

10. Cecere, L., (2012). Integrated Demand Management: When Will We Start Using Downstream Data? Supply Chain Insights LLC

11. Collins, D.E., Rappold, J.A., Murray, D.H., \& Muckstadt, J., (2001). "Guidelines for Collaborative Supply Chain System Design and Operation”, Technical Report No. 1286, School of Operational Research and Industrial Engineering, Cornel University, ICHACA, NY

12. Coltman, T.R., Devinney, T.M., \& Midgley, D.F., (2009). "Customer Relationship Management \& Firm Performance, Faculty \& Research Working Paper", The Business School for the World, INSTEAD Printers, France.

13. Costantino, F., Di Gravio, G., Shaban, A., \& Tronci, M., (2013). "Exploring the Bullwhip Effect \& Inventory Stability in a Seasonal Supply Chain", International Journal of Engineering Business Management: Special Issue on Innovations in Fashion Industry, DOI: 10.5772/56833, Vol. 5 
International Journal of Managing Value and Supply Chains (IJMVSC) Vol.5, No. 3, September 2014

14. deMin, J.E., (2005). "Collaborative Planning, Forecasting and Replenishment (CPFR) and the Network: Cracking the Bullwhip!” BT Infonet, Insight Matters, Vol.3.

15. Ertek, G., \& Eryılmaz, E. (2008) "The bullwhip effect in supply chain: Reflections after a decade." Working Paper, CELS 2008, Jonkoping, Sweeden presented by Emre Eryilmaz, Sabanci University, Orhanli, Tuzla, Turkey

16. Evans, D., \& Bretstein, S., (2010). Revolutionizing The Downstream Supply Chain: Getting product to market more profitably using best fit technology and processes, (C) Wipro Technologies

17. Grazdane, I., (2013). “A Customer Relationship Management Approach for Optical Retail Business", Master's thesis, Helsinki Metropolia University of Applied Sciences

18. Grean, M., \& Shaw, M.J, "Supply chain integration through information sharing: Channel Partnership between Wal-Mart and Procter \& Gamble", year_

19. Keramati, A., Mehrabi, H., \& Mojir, N., (2010). "A process-oriented perspective on customer relationship management and organizational performance: An empirical investigation”, Industrial Marketing Management, Vol. 39, pp. 1170-1185

20. Krejcie, R.V., \& Morgan, D.W., (1970). "Determining Sample Size for Research Activities", Educational and Psychological Measurement, 1970, 30, pp. 607-610.

21. Lee, H.L., Padmanabhan, V., \& Whang; S., (1997). "The Bullwhip Effect in Supply Chains", Sloan Management Review, Vol. 38, Issue 3, pp. 93-102

22. Lysons, K., \& Farrington, B. (2006). Purchasing \& supply chain management $\left(7^{\text {th }}\right.$ ed.). Harlow: Prentice-Hall, Pearson Education Ltd.

23. Mabonga, E. (2012). "Working capital management and competitiveness of small and medium enterprises", Unpublished PhD thesis, Kampala International University

24. Matovu, J., (2006). "Towards a management information system for public administration in Uganda", Unpublished Doctoral thesis, University of Zululand

25. Mishra, A., \& Mishra, D., (2009). "Customer Relationship Management: Implementation Process Perspective", Acta Polytechnica Hungarica, Vol. 6, No. 4

26. Mursu, A., (2002). "Information systems development in developing countries: risk management and sustainability analysis in Nigerian software companies", University library of Jyvaskyla, publishing unit, ISSN 1456-5390

27. Namagembe, S., (2010). "Information sharing, inventory management and customer satisfaction in the downstream chain of manufacturing firms in Uganda", Unpublished Master's thesis, Makerere University Business School

28. NDA Report (2011). "Licensed Pharmaceutical Companies in Uganda", (C Uganda National Drug Authority, Ministry of Health, Uganda

29. Oates, G.J., (2006). "An assessment of information flow as an enabler to supply chain collaboration in the supply chain within a South African Context", Master's thesis, University of Pretoria

30. Romano, P., \& Danese, P., (2011). "Performance Measurement Systems and Downstream Integration", International Conference on E-business, Management and Economics, IPEDR vol.3, IACSIT Press, Hong Kong

31. Schlacter, G., (2008). "How OEM Consumer Electronics Companies Can Dramatically Improve Profits Through Downstream Supply Chain Collaboration Directly With Retailers", An Oracle White Paper, Oracle Corporation, U.S.A

32. Sweeney, E. (2006). "Managing information flows: The Key to Effective Supply Chain Integration", Journal of the National Institute for Transport and Logistics, Vol. 9, No. 3.

33. Todeva, E. \& Knoke, D., (2005). "Strategic Alliances \& Models of Collaboration, Management Decision", Vol. 43:1.

34. Walters, D., (2009). Supply Chain Management: An Introduction to Logistics (2 ${ }^{\text {nd }}$ ed.). Palgrave MacMillan.

35. Weitz, B.A., Castleberry, S.B., \& Tanner, J.F., (2009). Selling: Building Partnerships (7 $7^{\text {th }}$ ed). McGraw-Hill Irwin, New York, USA 
International Journal of Managing Value and Supply Chains (IJMVSC) Vol.5, No. 3, September 2014

\section{Author:}

Samuel Pule is an Assistant Lecturer at Kampala International University. He holds a Master's of Science in Supply Chain Management from Kyambogo University, a Masters of Business Administration (Finance \& Accounting) from Kampala International University, a Post-graduate Diploma in Project Planning \& Management from Uganda Management Institute, a Post-graduate Certificate in Research Methods \& Writing Skills from Centre for Basic Research, and a Bachelors degree in Procurement \& Supplies Management from Kampala International University. He is also a member of the Institute of Procurement Professionals of Uganda.

Charles Kalinzi is a Lecturer and Head of Department (Procurement, Marketing \& Supply Chain Management) at Kyambogo University. $\mathrm{He}$ is a $\mathrm{PhD}$ Candidate and holds an MBA specializing in Management of Government Procurement from Maastricht School of Management, a Bachelor of Science degree in Mathematics \& Economics from Kyambogo University, A Post graduate Diploma in Education from Kyambogo University and a Certificate in Project Planning \& Management from Kyambogo University. He has also attended an advanced certificate course in advanced public procurement with International Development Law Organisation (IDLO) and a Procurement Strategy Development course with United Nations Development Programme. 